\title{
Chemical characterization of marine fish of low-commercial value and development of fish burgers
}

\author{
Danielle Regis Pires ${ }^{(1)}$, Amanda Lima Albuquerque Jamas ${ }^{(1)}$, Elizete Amorim ${ }^{(1)}$, \\ Cristiane Hess de Azevedo-Meleiro(1), Pedro Paulo de Oliveira Silva(1) and Gesilene Mendonça de Oliveira(1) \\ (1)Universidade Federal Rural do Rio de Janeiro (UFRRJ), Instituto de Tecnologia, Departamento de Tecnologia de Alimentos, Rodovia BR- \\ 465, Km 7, Campus Universitário, Zona Rural, CEP 23851-970 Seropédica, RJ, Brazil. E-mail: danielleregispires@hotmail.com, amanda. \\ jamas@yahoo.com.br, amorizete@ufrrj.br, hesscris@gmail.com, ppos@ufrrj.br, gesilene@ufrrj.br
}

\begin{abstract}
The objective of this work was to perform the chemical characterization of marine bonefish (Albula vulpes) and the development of fish burgers. Three formulations of fish burgers were prepared, containing 5,8 , and $10 \%$ cassava starch and functional ingredients (onion, garlic, and ground white pepper). Proximate composition, microbiological and $\mathrm{pH}$ analyses of the raw material, and fish burgers were performed, as well as the sensory analyses of the fish burgers. The yield and nutritional value of bonefish was found to be comparable with those of species of commercial value, with high-protein and low-lipid contents. The protein

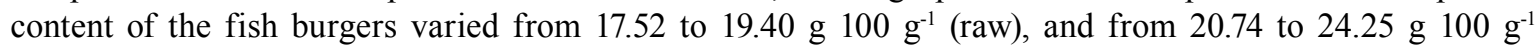

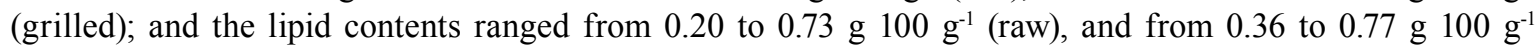
(grilled). In the sensory tests, the formulations received scores between six and seven on the nine-point hedonic scale. Acceptance indexes were higher than $70 \%$ for all the assessed attributes. Therefore, the use of this underutilized species proves to be feasible.
\end{abstract}

Index terms: Albula vulpes, bycatch species, functional ingredients, marine bonefish, sensory analysis.

\section{Caracterização química de pescado marinho de baixo valor comercial e desenvolvimento de hambúrguer de peixe}

\begin{abstract}
Resumo - O objetivo deste trabalho foi caracterizar quimicamente o pescado marinho ubarana (Albula vulpes) e desenvolver hambúrguer de peixe. Foram preparadas três formulações de hambúrguer de peixe, com 5, 8 e 10\% de fécula de mandioca e ingredientes funcionais (cebola, alho e pimenta-do-reino). Foram realizadas análises centesimais, microbiológicas e do $\mathrm{pH}$ da matéria-prima, assim como análises sensoriais dos hambúrgueres de peixe. O pescado ubarana apresentou rendimento e valor nutricional comparáveis aos de espécies de valor comercial, com elevado teor proteico e baixo teor de lipídios. Os teores de proteínas dos hambúrgueres de peixe variaram entre 17,52 e 19,40 g $100 \mathrm{~g} \mathrm{~g}^{-1}$ (crus) e 20,74 e 24,25 g $100 \mathrm{~g} \mathrm{~g}^{-1}$ (grelhados), e

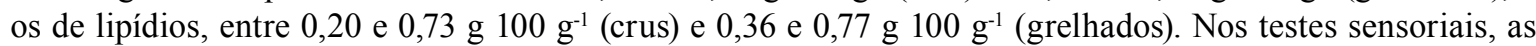
formulações receberam notas entre seis e sete na escala hedônica de nove pontos. Os índices de aceitação foram superiores a $70 \%$ para todos os atributos avaliados. Assim, o aproveitamento desta espécie subutilizada mostra-se viável.
\end{abstract}

Termos para indexação: Albula vulpes, captura de pescado acompanhante, ingredientes funcionais, pescado ubarana, análise sensorial.

\section{Introduction}

Fish belong to a food group of nutritional importance, as it provides health benefits such as a balanced supply of proteins, essential amino acids, and omega-3 fatty acids (Larsen et al., 2011).

Over the years, there has been a considerable increase of annual fish production and consumption, with global and national production near 168.0 and 1.5 million tonnes, respectively (Brasil, 2013; FAO,
2016). While the annual consumption of fish worldwide exceeds $20 \mathrm{~kg}$ per capita, national consumption is close to $12 \mathrm{~kg}$ per capita, as indicated by the World Health Organization (WHO) (Brasil, 2013; FAO, 2016).

In addition to the increase of production, there has also been an increase of the disposal of species with low or no commercial value, which are unintentionally caught during extractive fishing of high-value target species. According to Davies et al. (2009), bycatch 
species account for $40.4 \%$ of the total marine fish caught globally, corresponding to about 38.5 million tonnes discarded fish per year. One of the main reasons for this is the lack of economic or technological value of many fish species. Brazil is part of the Group for the Sustainable Management of Unintentional Catch in Latin America, whose objectives are to improve institutional and regulatory measures for the management of unintentional catch, and to optimize the use of bycatch species through sustainable alternatives (FAO, 2014).

Some authors have used bycatch species to develop products such as bread enriched with Prionotus punctatus proteins (Centenario et al., 2007), fish burgers made from Argyrosomus regius (Silva \& Fernandes, 2010), and fish crackers from Menticirrhus americanus and Umbrina coroides (Neiva et al., 2011).

In addition to research, there is a cooperation agreement with the Fundo Nacional de Desenvolvimento Escolar (FNDE), for the development of interventions aimed at the inclusion of fish in school meals. According to the Programa Nacional de Alimentação Escolar (PNAE), 30\% of the foodstuff served in these meals must come from family farming, artisanal fishing, and family aquaculture. The inclusion of fish in school meals will create a demand for foods with a strong stimulus to local socioeconomic development, while practicing healthy and adequate nutrition habits. Fish can be included in school meals in a variety of ways, such as roasted, grilled, and in sauce. In addition to traditional preparations, it can also be served as fish loaf, fish burgers, fish balls, and other dishes. Some Brazilian municipalities have already been able to fully meet the PNAE requirements, and can supply their products for school meals (FNDE, 2013). In addition to providing foods with high-nutritional value to students, the use of low-commercial value species in school meals represents an alternative for fishing communities, contributing to job creation and additional income for fishermen. Products containing high levels of animal fat, as well as food additives, have been criticized for being potentially harmful. The use of cassava starch as a substitute for fat, and functional ingredients (garlic, onion, and ground white pepper) in foods will allow healthier products to be produced at a lower cost (Seabra et al., 2002; Park \& Chin, 2010; Zhang et al., 2015).
The species Albula vulpes (Linnaeus, 1758), commonly known as bonefish, inhabits tropical and subtropical coastal marine environments, and it is commonly caught in sport fishing (Cooke et al., 2008). In extractive fishing activities, bonefish is unintentionally caught together with high-commercial value species. Although it is rich in meat, it is hardly consumed for its many small bones (Lopes et al., 2001).

There is a tradition of artisanal fishing in the Sepetiba Bay region, one of the main fishing hubs in the state of Rio de Janeiro, Brazil. In 2014, 373,260 kg of mullet were landed in this state, along with 13,876 $\mathrm{kg}$ of bonefish (Fundação Instituto de Pesca do Estado de Rio de Janeiro, 2014). Bonefish, a bycatch of an important species captured in Sepetiba Bay, is already being landed; it is therefore essential to understand its nutritional value, and to create strategies to explore this bycatch.

The objective of this work was to perform the chemical characterization of marine bonefish and the development of fish burgers.

\section{Materials and Methods}

Bonefish (A. vulpes) samples were obtained from artisanal fishermen in Sepetiba Bay fishing communities $\left(22^{\circ} 55^{\prime}\right.$ to $23^{\circ} 03^{\prime} \mathrm{S}, 43^{\circ} 48^{\prime}$ to $\left.44^{\circ} 02^{\prime} \mathrm{W}\right)$, located in the municipalities of Itaguaí and Rio de Janeiro, RJ, Brazil. The collection of samples was carried out during each season of the year between April 2014 and January 2015. Five samples were obtained with the aim at analyzing the proximate composition and $\mathrm{pH}$ of the species. Forty-eight fish, obtained during the spring season, were used for the preparation of fish burgers, and for the subsequent microbiological, $\mathrm{pH}$, proximate composition, and sensory analyses.

The obtained fresh specimens were transported to the Departamento de Tecnologia de Alimentos, of Universidade Federal Rural do Rio de Janeiro, and stored with ice flakes in isothermal boxes at 1:1 ratio (fish:ice).

The bonefish samples obtained at each station were analyzed for proximate composition (moisture, ash, lipid, and protein contents) and $\mathrm{pH}$. Moisture was determined through gravimetric analysis in a chamber at $105^{\circ} \mathrm{C}$. Protein content was evaluated following the Kjeldahl method (conversion factor 6.25, used for 
fish in this methodology). Lipids were extracted with hexane, and quantified using a Soxhlet extractor. Ash content was measured using gravimetric analysis by incinerating organic matter, followed by calcination in a furnace at $550^{\circ} \mathrm{C}$. All cited methodologies were based on the protocols specified by Adolfo Lutz Institute (Procedimentos..., 2008).

The 48 whole fish used for the preparation of burgers were individually weighed and measured using a Ramuzatron-15 scale (Ramuza Indústria e Comércio de Balanças Ltda., Santana do Parnaíba, SP, Brazil) and a measuring tape. Fish were then washed and cleaned, and skinless fillets were obtained. Meat attached to the carcass was removed with a spoon. The fillets and the meat removed from the carcass were then passed through a PSE-10 grinder (Metalúrgica Siemsen Ltda., Brusque, SC, Brazil) with a $5 \mathrm{~mm}$ diameter disc to obtain ground fish meat (GFM). Weight measurements were made at every step of the process, in order to calculate the yield. The percentages of fillet with skin, without skin, of GFM (fillet without skin, and meat removed from the carcass), and residues (head, viscera, skin, carcass, scales, flippers, and fins) were calculated in relation to the total weight of the whole fish.

Three formulations, based on previous laboratory studies, were adopted for the preparation of the fish burgers, following the parameters described by Seabra et al. (2002), who produced mutton burgers with fat substitutes such as cassava starch. The following ingredients were used: bonefish GFM, cassava starch, ice water, refined salt, garlic powder, onion powder, and white pepper (Table 1). Cassava starch, garlic, onion, and white pepper were purchased in powder form (Polico Comercial de Alimentos Ltda., São Paulo, SP, Brazil). The ingredients were weighed and placed in polyethylene trays, in which the mixture for each formulation was manually homogenized for $1 \mathrm{~min}$. The mixture was then left to rest under refrigeration for 1 hour. Subsequently, the mixture of each formulation was separated into 100 $\mathrm{g}$ portions, and the fish burgers were shaped using an aluminum burger mold of 11x12.5 cm (Gallizzi, São Paulo, SP, Brazil). The fish burgers were then packed in hermetically sealed zip-lock containers with a capacity of up to $2 \mathrm{~L}$ (Ziploc, S.C. Johnson \& Son, Inc., Rio de Janeiro, RJ, Brazil), and stored in a freezer at $-18^{\circ} \mathrm{C}$ until analysis.
The fish burgers were grilled using a home appliance (Vicini Di Casa Grill and Sandwich Maker EPV-826 LOT HCL 088/10) for $15 \mathrm{~min}$, and they were turned every 3 min until the internal temperature of $100{ }^{\circ} \mathrm{C}$ was reached.

Microbiological analyses (for coagulase-positive Staphylococcus and Salmonella spp.) were performed on fresh fish meat used in the preparation of the burgers, as well as on raw fish burgers (coagulase-positive Staphylococcus, Salmonella spp., and coliforms, at $45^{\circ} \mathrm{C}$ ) (Anvisa, 2001). Proximate composition and $\mathrm{pH}$ analyses were carried out for the three formulations, for both raw and grilled fish burgers, as previously described (Procedimentos..., 2008).

For the sensory analyses, 108 untrained evaluators of both genders and different ages were randomly recruited among students, teachers, and employees of the University (UFRR). There was no predominance of gender, with $50 \%$ (54) male and 50\% (54) female participants. The predominant age group was from 21 to 30 -year-old people, corresponding to $78.70 \%$ (85) of participants, followed by the age groups of 31 to 40 -year-old persons $(8.33 \%), 18$ to 20 year-old persons $(7.41 \%), 41$ to 50 -year-old persons $(3.70 \%)$, and 51 year-old or older persons $(0.93 \%)$. One person $(0.93 \%)$ did not indicate his/her age group.

The grilled fish burger samples were transported in capped aluminum containers to the test site. Each evaluator simultaneously received three samples of 25 $\mathrm{g}$ each, corresponding to $1 / 4$ of a fish burger of each formulation. The samples were served in disposable plastic dishes, coded with a random three-digit number. The evaluators were given mineral water at room temperature, and water crackers to cleanse their palates between sample tasting. They were also given a

Table 1. Ingredient percentages used in the formulations of the three burgers based on ground fish meat (GFM) of bonefish (Albula vulpes).

\begin{tabular}{lccc}
\hline Ingredient & Formulation I & Formulation II & Formulation III \\
\hline GFM (\%) & 81.0 & 78.0 & 76.0 \\
Cassava starch (\%) & 5.0 & 8.0 & 10.0 \\
Ice water (\%) & 10.0 & 10.0 & 10.0 \\
Refined salt (\%) & 1.0 & 1.0 & 1.0 \\
Garlic powder (\%) & 1.0 & 1.0 & 1.0 \\
Onion powder (\%) & 1.0 & 1.0 & 1.0 \\
White pepper (\%) & 1.0 & 1.0 & 1.0 \\
\hline Total (\%) & 100 & 100 & 100 \\
\hline
\end{tabular}

Pesq. agropec. bras., Brasília, v.52, n.11, p.1091-1098, nov. 2017 DOI: $10.1590 / \mathrm{S} 0100-204 X 2017001100015$ 
sensory evaluation worksheet and an informed consent form.

A quantitative affective test was used, with acceptance and rank-order tests for assessing preference. The sensory evaluation worksheets also included preliminary questions (gender, age, and dietary habits regarding fish consumption), with the aim at tracing the profile of the evaluators, and final questions assessing their willingness to purchase the evaluated products. The nine-point hedonic scale was used for the acceptance test, which contained statements that ranged from "I liked it very much" to "I didn't like it at all," and the intermediate statement "I neither liked nor disliked it". The overall appearance, color, aroma, taste, and texture attributes of the fish burgers from each sample were evaluated. In the rankorder test, the evaluators ranked the three samples for global preference from worst to best (Procedimentos..., 2008; Minim, 2013). The acceptance index (AI) was calculated using the following equation: $\mathrm{AI}=\mathrm{A} \times 100 / \mathrm{B}$, in which $\mathrm{A}$ represents the average obtained for the formulation, and B represents the maximum grade given to it (Dutcosky, 1996).

For proximate composition analysis, Tukey's test at $5 \%$ probability was applied using the XLSTAT software. The results of the sensory tests were evaluated using the variance analysis and the Tukey's test, at 5\% probability, using the XLSTAT software. The Friedman test was applied for the rank-order test, using the Newell \& MacFarlane table for interpretation of results (Newell \& MacFarlane, 1987).

The present study was submitted to the UFRRJ Ethics Committee under the process no. 23083.000673 / 2015-87, and it was approved under the protocol no. 558/2015 (March 24, 2015).

\section{Results and Discussion}

The proximate composition of bonefish during the four seasons of the year showed a moisture content variation (Table 2) similar to that observed in fish species studied by Viana et al. (2013). In the present study, fish moisture content is essential to determine its shelf life and to define appropriate methodologies for its preservation. Moisture content in the winter samples resembled that of tilapia observed by Souza et al. (2004), and that of yellowtail snapper (Ocyurus chrysurus) observed by Andrade et al. (2009). The samples collected during the summer yielded values close to those observed by Andrade et al. (2009) in mullet (Mugil cephalus).

The protein content also varied, in agreement with the observations of Viana et al. (2013) in lane snapper (Lutjanus synagris), yellowtail snapper (O. chrysurus), Atlantic thread herring (Opisthonema oglinum), and mullet (M. cephalus). The protein content values of bonefish were most similar to those of mullet. Menezes et al. (2008) and Andrade et al. (2009) also evaluated the protein content of mullet and obtained values of $20.85 \%$ and $20.26 \%$, respectively, which are very close to those observed for bonefish, especially in the

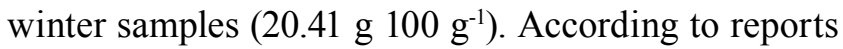
from artisanal fishermen in Sepetiba Bay, bonefish is unintentionally caught as bycatch of mullet. The samples collected in autumn showed a similar protein content to that of red snapper (L. purpureus), and curimatã (Prochilodus cearenses) (Caula et al., 2008). The summer sample showed a high-protein content; only tilapia showed a higher-protein content than that of bonefish (Souza et al., 2004). It is noteworthy that while bonefish does not have commercial value, it has a high-protein content, with levels similar to those of target-catch species. This is an important factor in the creation of strategies for its use.

Table 2. Proximate composition and $\mathrm{pH}$ of bonefish (Albula vulpes), in the four seasons of the year during April 2014 to January $2015^{(1)}$.

\begin{tabular}{|c|c|c|c|c|}
\hline \multirow[t]{2}{*}{ Variable } & \multicolumn{4}{|c|}{ Bonefish composition } \\
\hline & Autumn & Winter & Spring & Summer \\
\hline Moisture (g $\left.100 \mathrm{~g}^{-1}\right)$ & $74.70 \pm 0.99 b c$ & $78.68 \pm 0.19 \mathrm{a}$ & $76.40 \pm 0.19 \mathrm{~b}$ & $73.42 \pm 0.33 \mathrm{c}$ \\
\hline Protein $\left(\mathrm{g} 100 \mathrm{~g}^{-1}\right)$ & $18.34 \pm 0.60 \mathrm{c}$ & $20.41 \pm 0.48 b$ & $21.58 \pm 0.84 \mathrm{~b}$ & $23.62 \pm 0.89 \mathrm{a}$ \\
\hline Lipid $\left(g 100 g^{-1}\right)$ & $0.98 \pm 0.01 \mathrm{~b}$ & $0.06 \pm 0.00 \mathrm{~d}$ & $0.61 \pm 0.01 \mathrm{c}$ & $1.55 \pm 0.07 \mathrm{a}$ \\
\hline $\operatorname{Ash}\left(g_{\left.100 g^{-1}\right)}\right.$ & $1.57 \pm 0.01 \mathrm{a}$ & $1.41 \pm 0.07 \mathrm{a}$ & $1.14 \pm 0.04 \mathrm{~b}$ & $1.16 \pm 0.04 \mathrm{~b}$ \\
\hline $\mathrm{pH}$ & 6.3 & 6.3 & 6.1 & 6.0 \\
\hline
\end{tabular}

${ }^{(1)}$ Means with different letters, in the same line, differ significantly according to the Tukey's test, at 5\% probability. 
The range of the lipid content was higher than that reported by Viana et al. (2013) for all studied species. According to Bijayalakshmi et al. (2014), the moisture content is inversely proportional to the lipid content. Their study showed inversely proportional values for moisture and lipid content in Channa striata species. This result was corroborated by the present work, in which the moisture contents of the summer and winter samples were inversely proportional to the lipid contents. An accumulation of energy is observed in fish prior to the reproductive period, when the lipid stock is spent. Seasonal gonadal activity is observed in bonefish, with a peak during the colder months of the year (Crabtree et al., 1997). This could explain why lipid content was lower in winter than in the other seasons. Winter samples had a lower-lipid value than those found in the literature, probably because bonefish is a species with low-lipid content in its reproductive period at that time of the year. Autumn samples showed lipid content close to that of the red snapper (Caula et al., 2008). Spring samples showed a lipid content closest to the lowest value observed in yellowtail snapper (Viana et al., 2013). Summer samples held the highest-lipid content, with a value close to that observed in lane snapper (Andrade et al., 2009).

Ash content range in bonefish was similar to that observed in mullet (Viana et al., 2013). Ashes represent the mineral content of the fish musculature, and vary according to their diet. Probably, bonefish consume the same feeds as that of mullet, the target species to which it is the bycatch. The $\mathrm{pH}$ values observed in each season (Table 2) complied with legislation (less than 7.0) (Brasil, 2017).

Observed weights for bonefish ranged from 285 to $1,925 \mathrm{~g}$, with the average of $818 \mathrm{~g}$. The length ranged from 37.00 to $65.00 \mathrm{~cm}$, with the average of $49.96 \mathrm{~cm}$. The total weight of fillets with skin, without skin, and of the removed meat from the carcass were 17.315, 11.636 , and $3.885 \mathrm{~kg}$, respectively. The average yield of fillets with skin, without skin, and in GFM (fillet without skin, and meat removed from the carcass) were 44.10, 29.64, and 39.53\%, respectively. The obtained average percentage of residues (head, viscera, skin, carcass, scales, flippers, and fins) was $60.41 \%$.

Bonefish average weight and length, as well as the amount of residues, were close to those observed for Nile tilapia (Oreochromis niloticus) (Simões et al., 2007). The yield obtained from bonefish was similar to that from species of commercial value.

In a $25 \mathrm{~g}$ sample of bonefish fresh meat, a value of $<1.0 \times 10^{2} \mathrm{CFU} \mathrm{g}^{-1}$ was found for coagulase-positive Staphylococcus; and Salmonella spp. was not detected, which complies with the legislation. In fish burgers, microbiological analyses yielded a value of $<1.0 \times 10^{2}$ CFU $\mathrm{g}^{-1}$ for coagulase-positive Staphylococcus, absence of Salmonella spp., and a value of $<3.0$ for thermotolerant coliforms, which complies with the legislation (Anvisa, 2001). Adding the ingredients to bonefish meat caused $\mathrm{pH}$ to decrease to 5.7 in all formulations. After cooking the burgers, the $\mathrm{pH}$ in all formulations increased to 6.1. All $\mathrm{pH}$ results for fish burgers complied with the legislation (Brasil, 2017).

In raw fish burgers, the moisture, protein, and lipid contents decreased gradually with a gradual increase of cassava starch concentration (Table 3). As starch was added, the water retention capacity of the products was increased, which naturally decreased the moisture content. Starch concentration was inversely proportional to that of GFM, which may be attributed to the reduction of protein and lipid contents. Conversely, the carbohydrate content and the caloric

Table 3. Proximate composition of raw and grilled fish burgers, prepared following three different formulations ${ }^{(1)}$ using bonefish ground meat (Albula vulpes) ${ }^{(2)}$.

\begin{tabular}{|c|c|c|c|c|c|c|}
\hline \multirow[t]{2}{*}{ Composition } & \multicolumn{3}{|c|}{ Raw fish burger } & \multicolumn{3}{|c|}{ Grilled fish burger } \\
\hline & Formulation I & Formulation II & Formulation III & Formulation I & Formulation II & Formulation III \\
\hline Moisture $\left(\mathrm{g} 100 \mathrm{~g}^{-1}\right)$ & $72.23 \pm 0.12 \mathrm{a}$ & $69.68 \pm 0.18 b$ & $67.77 \pm 0.31 \mathrm{c}$ & $64.07 \pm 0.03 \mathrm{~A}$ & $63.23 \pm 0.01 \mathrm{~A}$ & $62.58 \pm 1.94 \mathrm{~A}$ \\
\hline Protein $\left(\mathrm{g} 100 \mathrm{~g}^{-1}\right)$ & $19.40 \pm 0.10 \mathrm{a}$ & $18.77 \pm 0.21 \mathrm{a}$ & $17.52 \pm 0.42 b$ & $24.25 \pm 0.14 \mathrm{~A}$ & $22.11 \pm 0.43 \mathrm{~B}$ & $20.74 \pm 0.42 \mathrm{C}$ \\
\hline Lipid $\left(g 100 \mathrm{~g}^{-1}\right)$ & $0.73 \pm 0.03 \mathrm{a}$ & $0.59 \pm 0.06 \mathrm{a}$ & $0.20 \pm 0.02 b$ & $0.77 \pm 0.08 \mathrm{~A}$ & $0.61 \pm 0.02 \mathrm{~A}$ & $0.36 \pm 0.01 \mathrm{~B}$ \\
\hline $\operatorname{Ash}\left(g_{\left.100 g^{-1}\right)}\right.$ & $1.14 \pm 0.06 \mathrm{~b}$ & $1.92 \pm 0.08 \mathrm{a}$ & $2.09 \pm 0.11 \mathrm{a}$ & $2.37 \pm 0.10 \mathrm{~A}$ & $2.24 \pm 0.10 \mathrm{~A}$ & $2.42 \pm 0.20 \mathrm{~A}$ \\
\hline Carbohydrate $\left(\mathrm{g} 100 \mathrm{~g}^{-1}\right)$ & $6.50 \pm 0.08$ & $9.04 \pm 0.13$ & $12.08 \pm 0.22$ & $8.54 \pm 0.09$ & $11.81 \pm 0.14$ & $13.90 \pm 0.64$ \\
\hline Energy (kcal $100 \mathrm{~g}^{-1}$ ) & 110.17 & 116.55 & 120.20 & 138.09 & 141.17 & 141.64 \\
\hline
\end{tabular}

${ }^{(1)}$ For composition of formulations FI, FII, and FIII, see Table 1. ${ }^{(2)}$ Mean values with different letters, in the same line, differ according to the Tukey's test, at $5 \%$ probability. 
value of the three formulations increased gradually as starch concentration increased.

Mello et al. (2012) and Marengoni et al. (2009) found that raw Nile tilapia burgers had highermoisture contents than bonefish burgers evaluated in the present study. This occurred because they did not use starch (Mello et al., 2012), or they used it in lower concentrations (Marengoni et al., 2009) in their formulations. Protein contents in fish burgers prepared by Mello et al. (2012) were close to those observed for formulations II and III. Marengoni et al. (2009) reported values lower than those found in the present study, while considerably higher values were found by Silva \& Fernandes (2010) for corvina burgers (A. regius). It has been reported that the addition of starch and its higher concentration in the formulations are responsible for reduced protein content, which is consistent with the results presented here.

Lipid contents of the present study are lower than those found by Marengoni et al. (2009) and Mello et al. (2012) for Nile tilapia burgers, and similar to those found by Silva \& Fernandes (2010) for corvina burgers.

Ash contents of the products of the present work are lower than those prepared by Marengoni et al. (2009) and by Mello et al. (2012). However, ash contents of the formulations I and II are similar to the results reported by Silva $\&$ Fernandes (2010). Carbohydrate content and the caloric value of fish burgers were not evaluated in most of the cited literature in the present work. The carbohydrate content of formulation I was similar to that of corvina burgers. The results obtained for bonefish burgers were most similar to those obtained for corvina, probably because both species are classified as containing low-lipid levels and, therefore, they have the most similar proximate composition.

The proximate composition of the fish burgers changed after preparation. The moisture content in grilled fish burgers was lower than in raw burgers. This result is attributed to the loss of water that occurs during preparation (Table 3). The protein, lipid, ash, carbohydrate, and caloric contents of grilled fish burgers were higher than those of raw fish; this is also owing to loss of water, which affects the concentration values.

After profiling fish consumers, 95.37\% (103) stated that they considered eating fish to be healthy, and $77.78 \%$ (84) stated that they eat fish regularly. Regarding the frequency of fish consumption, $36.11 \%$ (39) stated that they consume it occasionally, $15.74 \%$ (17) monthly, $26.85 \%$ (29) fortnightly, $12.96 \%$ (14) weekly, and $3.70 \%$ (4) more than once a week. As to the type of fish preparation consumed, some evaluators listed more than one option. The predominant type of fish preparation was fried, marked by $53.70 \%$ (58) of the evaluators, followed by roasted/grilled with 48.15\% (52); boiled 43.52\% (47), pre-cooked 9.26\% (10), and other ways $5.56 \%$ (6). Regarding the "in other ways" option, the evaluators stated they consume raw fish as a Japanese food item. Although most evaluators consider eating fish healthy, they do not consume it often. "Occasionally" and "fortnightly" were the most common consumption frequencies, whereas a minority selected "weekly" and "more than once a week." Clearly, the consumption of this food is not routine. Furthermore, the predominant form of consumption was the least healthy (fried).

The results of the acceptance tests for general appearance, color, aroma, and taste attributes yielded a score of seven, classified as "liked moderately", and texture received a score of six, corresponding to "liked it mildly" (Table 4). The scores for all attributes were slightly higher in formulation II.

For Nile tilapia burgers, Fogaça et al. (2015) reported scores of approximately seven for general appearance and aroma, and six for taste and texture. The results

Table 4. Sensory evaluation by the nine-point hedonic scale (HS), from 1 ("I didn't like it at all") to 9 ("I really liked it"), and acceptance index (AI) for general appearance, color, aroma, taste, and texture of fish burgers prepared following three different formulations ${ }^{(1)}$ using bonefish ground meat (Albula vulpes) $)^{(1)}$.

\begin{tabular}{|c|c|c|c|c|c|c|c|c|c|c|}
\hline \multirow[t]{2}{*}{ Formulation $^{(2)}$} & \multicolumn{2}{|c|}{ General appearance } & \multicolumn{2}{|c|}{ Color } & \multicolumn{2}{|c|}{ Aroma } & \multicolumn{2}{|c|}{ Taste } & \multicolumn{2}{|c|}{ Texture } \\
\hline & HS & AI (\%) & HS & AI (\%) & HS & AI (\%) & HS & AI (\%) & HS & AI (\%) \\
\hline I & $7.21 \mathrm{a}$ & 80.14 & $7.16 \mathrm{a}$ & 79.53 & $7.12 \mathrm{a}$ & 79.16 & $7.23 \mathrm{a}$ & 80.35 & $6.75 \mathrm{a}$ & 75.00 \\
\hline II & $7.54 \mathrm{a}$ & 83.74 & $7.44 \mathrm{a}$ & 82.61 & $7.36 \mathrm{a}$ & 81.79 & $7.31 \mathrm{a}$ & 81.28 & $6.99 a$ & 77.67 \\
\hline III & $7.27 \mathrm{a}$ & 80.76 & $7.11 \mathrm{a}$ & 79.01 & $7.08 \mathrm{a}$ & 78.70 & $7.02 \mathrm{a}$ & 77.98 & $6.55 \mathrm{a}$ & 72.74 \\
\hline
\end{tabular}

${ }^{(1)}$ Mean values with different letters, in the same line, differ according to the Tukey's test, at $5 \%$ probability. ${ }^{(2)}$ For composition of formulations FI, FII, and FIII, see Table 1. 
for the general appearance and aroma attributes were similar to those obtained in the present study; however, bonefish flavor ranked lower. Furthermore, the lowest score was obtained for the texture parameter. Marengoni et al. (2009) and Mello et al. (2012) obtained scores of around seven for all evaluated parameters with Nile tilapia burgers. Their results were similar to those of the present study, except for texture, which yielded better results than that of the present study.

All the attributes of the three formulations yielded AIs equal to or greater than $70 \%$. Formulation II showed the best AIs for all attributes. The highest AI was obtained for the overall appearance of formulation II, with a value similar to the general acceptance score for corvina burgers (Silva \& Fernandes, 2010).

According to the Newell \& MacFarlane table, used for the rank-order test (Friedman test), the critical difference between the ranking totals for three samples and 108 judges, at 5\% probability, was 34 . The absolute value of the difference between formulations I and II was 35; between formulations II and III, 43; and between formulations I and III, 8. As in the AI values for the various attributes, formulation II stood out as the preferred sample by the evaluators.

As to purchase intention, formulation II showed the best result, corroborating the previous results. Formulation I had the second largest purchase intention, and formulation III came last. Some evaluators (3.70\%) stated they would be willing to buy all the samples; others $(4.63 \%)$ said they would be interested in buying the product, but they did not specify which sample. A small percentage of evaluators $(3.70 \%)$ stated that they would not be interested in buying any of the samples. In general, it was determined that bonefish burgers would be well received in the consumer market. Therefore, the use of fish species of low-commercial value for the preparation of products with added value constitutes a good alternative for three reasons: nutrition, as it has a high-nutritional value; economic, by using a species that was previously discarded; and environmental, by reducing the disposal of organic matter in the environment.

\section{Conclusions}

1. Bonefish (Albuba vulpes) shows a high-nutritional value, with high-protein and low-lipid contents.
2. Fish burgers made using bonefish have a highnutritional value, and are well received by consumers.

\section{References}

ANDRADE, G. de Q.; BISPO, E. da S.; DRUZIAN, J.I. Avaliação da qualidade nutricional em espécies de pescado mais produzidas no Estado da Bahia. Ciência e Tecnologia de Alimentos, v.29, p.721-726, 2009. DOI: 10.1590/S0101-20612009000400004.

ANVISA. Agência Nacional de Vigilância Sanitária (Brasil). Resolução RDC $\mathbf{n}^{\mathbf{0}} \mathbf{1 2}$, de 2 de janeiro de 2001. [Aprova o Regulamento Técnico sobre os Padrões Microbiológicos para Alimentos]. Available at: <http://portal.anvisa.gov.br/ documents/33880/2568070/RDC_12_2001.pdf/15ffddf6-37674527-bfac-740a0400829b>. Accessed on: Sept. 302017.

BIJAYALAKSHMI, C.; NGASEPAM, R.S.; INDIRA, N.; SHOMORENDRA, M. Estimation of moisture and total lipid content of some small indigenous fishes of Manipur. International Journal of Science and Research, v.3, p.1091-1094, 2014.

BRASIL. Decreto n ${ }^{\circ}$ 9.013, de 29 de março de 2017. Regulamenta a Lei $\mathrm{n}^{\mathrm{o}} 1.283$, de 18 de dezembro de 1950 , e a Lei ${ }^{\circ} 7.889$, de 23 de novembro de 1989, que dispõem sobre a inspeção industrial e sanitária de produtos de origem animal. Available at: <http://www.saude.rj.gov.br/comum/code/MostrarArquivo. php?C=NzU2NQ\%2C\%2C >. Accessed on: Sept. 302017.

BRASIL. Ministério da Pesca e Aquicultura. Boletim estatístico da pesca e aquicultura 2011. Brasília, [2013]. 60p. Available at: <http://www.icmbio.gov.br/cepsul/images/stories/biblioteca/ download/estatistica/est_2011_bol_bra.pdf $>$. Accessed on: Sept. 302017.

CAULA, F.C.B.; OLIVEIRA, M.P. de; MAIA, E.L. Teor de colesterol e composição centesimal de algumas espécies de peixes do estado do Ceará. Ciência e Tecnologia de Alimentos, v.28, p.959-963, 2008. DOI: 10.1590/S0101-20612008000400031.

CENTENARIO, G.S.; FEDDERN, V.; BONOW, E.T.; SALASMELLADO, M. Enriquecimento de pão com proteínas de pescado. Ciência e Tecnologia de Alimentos, v.27, p.663-668, 2007. DOI: $10.1590 / \mathrm{S} 0101-20612007000300036$.

COOKE, S.J.; SUSKI, C.D.; DANYLCHUK, S.E.; DANYLCHUK, A.J.; DONALDSON, M.R.; PULLEN, C.; BULTÉ, G.; O'TOOLE, A.; MURCHIE, K.J.; KOPPELMAN, J.B.; SHULTZ, A.D.; BROOKS, E.; GOLDBERG, T.L. Effects of different capture techniques on the physiological condition of bonefish Albula vulpes evaluated using field diagnostic tools. Journal of Fish Biology, v.73, p.1351-1375, 2008. DOI: 10.1111/j.1095-8649.2008.02008.x.

CRABTREE, R.E.; SNODGRASS, D.; HARNDEN, C.W. Maturation and reproductive seasonality in bonefish, Albula vulpes, from the waters of the Florida keys. Fishery Bulletin, v.95, p.456-465, 1997.

DAVIES, R.W.D.; CRIPPS, S.J.; NICKSON, A.; PORTER, G. Defining and estimating global marine fisheries bycatch. Marine Policy, v.33, p.661-672, 2009. DOI: 10.1016/j.marpol.2009.01.003. 
DUTCOSKY, S.D. Análise sensorial de alimentos. Curitiba: Champagnat, 1996. 123p.

FAO. Food and Agriculture Organization of the United States. The state of world fisheries and aquaculture. Rome, 2014. Available at: <http://www.fao.org/3/dleaa9a1-5a71-4e42-86c0f2111f07de16/i3720e.pdf >. Accessed on: Nov. 222015.

FAO. Food and Agriculture Organization of the United States. The state of world fisheries and aquaculture. Rome, 2016. Available at: <http://www.fao.org/3/a-i5555e.pdf>. Accessed on: Feb. 192017.

FNDE. Fundo Nacional de Desenvolvimento da Educação. Nota técnica $n^{0} 4$, de 11 de julho de 2013. Inclusão do pescado na alimentação escolar. Brasília, 2013. Available at: <http://www.fnde. gov.br/centrais-de-conteudos/publicacoes/category/116-alimentacaoescolar?download=8692: nota-tecnica-n-04-2013-inclusao-depescado-na-alimentacao-escolar>. Accessed on: Sept. 302017.

FOGAÇA, F.H. dos S.; OTANI, F.S.; PORTELLA, C.de G.; SANTOS-FILHO, L.G.A. dos; SANTA'ANA, L.S. Caracterização de surimi obtido a partir da carne mecanicamente separada de tilápia do Nilo e elaboração de fishburger. Semina: Ciências Agrárias, v.36, p.765-776, 2015. DOI: 10.5433/1679-0359.2015v3 $6 \mathrm{n} 2 \mathrm{p} 765$.

FUNDAÇÃO INSTITUTO DE PESCA DO ESTADO DO RIO DE JANEIRO. Relatório final 2014. Niterói: FIPERJ, 2014. Available at: <http://www.icmbio.gov.br/cepsul/images/stories/ biblioteca/download/estatistica/rj/est_2014_relatorio.pdf $>$. Accessed on: Feb. 242017.

LARSEN, R.; EILERTSEN, K.-E.; ELVEVOLL, E.O. Health benefits ofmarine foods and ingredients. Biotechnology Advances, v.29, p.508-518, 2011. DOI: 10.1016/j.biotechadv.2011.05.017.

LOPES, P.R.D.; OLIVEIRA-SILVA, J.T. de; BISPO, S.C.; COELHO,M.Notasobreaalimentaçãodejuvenismetamorfoseados de Albula vulpes (Linnaeus, 1758) (Actinopterygii: Albulidae) na praia de Itapema (Baía de Todos os Santos), Bahia. Bioikos, v.15, p.11-16, 2001.

MARENGONI, N.G.; POZZA, M.S. dos S.; BRAGA, G.C.; LAZZERI, D.B.; CASTILHA, L.D.; BUENO, G.W.; PASQUETTI, T.J.; POLESE, C. Caracterização microbiológica, sensorial e centesimal de fishburgers de carne de tilápia mecanicamente separada. Revista Brasileira de Saúde e Produção Animal, v.10, p.168-176, 2009.

MELLO, S.C.R.P.; FREITAS, M.Q.; SÃO CLEMENTE, S.C.; FRANCO, R.M.; NOGUEIRA, E.B.; FREITAS, D.D.G.C. Development and bacteriological, chemical and sensory characterization of fishburgers made of Tilapia minced meat and surimi. Arquivo Brasileiro de Medicina Veterinária e Zootecnia, v.64, p.1389-1397, 2012. DOI: 10.1590/S010209352012000500041.

MENEZES, M.E. da S.; LIRA, G.M.; OMENA, C.M.B. de; FREITAS, J.D. de; SANT'ANA, A.E.G. Composição centesimal, colesterol e perfil de ácidos graxos dos peixes tainha (Mugil cephalus) e camurim (Centropomus undecimalis) da Lagoa Mundaú, AL/Brasil. Revista do Instituto Adolfo Lutz, v.67, p.89-95, 2008.

MINIM, V.P.R. (Ed.). Análise sensorial: estudos com consumidores. 3.ed. rev. e ampl. Viçosa: Ed. da UFV, 2013. 332p.

NEIVA, C.R.P.; MACHADO, T.M.; TOMITA, R.Y.; FURLAN, E.F.; LEMOS NETO, M.J.; BASTOS, D.H.M. Fish crackers development from minced fish and starch: an innovative approach to a traditional product. Ciência e Tecnologia de Alimentos, v.31, p.973-979, 2011. DOI: 10.1590/S0101-20612011000400024.

NEWELL, G.J.; MACFARLANE, J.D. Expanded tables for multiple comparison procedures in the analysis of ranked data. Journal of Food Science, v.52, p. 1721-1725, 1987. DOI: 10.1111/ j.1365-2621.1987.tb05913.x.

PARK, S.Y.; CHIN, K.B. Effects of onion physicochemical properties, lipid oxidation and microbial growth of fresh pork patties. International Journal of Food Science and Technology, v.45, p.1153-1160, 2010. DOI: 10.1111/j.1365-2621.2010.02245.x.

PROCEDIMENTOS e determinações gerais. In: ZENEBON, O.; PASCUET, N.S.; TIGLEA, P. (Coord.). Métodos físico-químicos para análise de alimentos. 4.ed. São Paulo: Instituto Adolfo Lutz, 2008. p.83-158.

SEABRA, L.M.J.; ZAPATA, J.F.F.; NOGUEIRA, C.M.; DANTAS, M.A.; ALMEIDA, R.B. de. Fécula de mandioca e farinha de aveia como substitutos de gordura na formulação de hambúrguer de carne ovina. Ciência e Tecnologia de Alimentos, v.22, p.244-248, 2002. DOI: 10.1590/S0101-20612002000300008.

SILVA, S.R. da; FERNANDES, E.C.S. Aproveitamento da corvina (Argyrosomus regius) para elaboração de fishburguer. Cadernos de Pesquisa, v.17, p.67-70, 2010.

SIMÕES, M.R.; RIBEIRO, C. de F.A.; RIBEIRO, S. da C.A.; PARK, K.J.; MURR, F.E.X. Composição físico-química, microbiológica e rendimento do filé de tilápia tailandesa (Oreochromis niloticus). Ciência e Tecnologia Alimentos, v.27, p.608-613, 2007. DOI: 10.1590/S0101-20612007000300028.

SOUZA, M.L.R. de; BACCARIN, A.E.; VIEGAS, E.M.M.; KRONKA, S. do N. Defumação da tilápia do Nilo (Oreochromis niloticus) inteira eviscerada e filé: aspectos referentes às características organolépticas, composição centesimal e perdas ocorridas no processamento. Revista Brasileira de Zootecnia, v.33, p.27-36, 2004. DOI: 10.1590/S1516-35982004000100005.

VIANA, Z.C.V.; SILVA, E. da; FERNANDES, G.B.; SANTOS, V.L.C.S. Composição centesimal em músculo de peixes no litoral do estado da Bahia/Brasil. Revista de Ciências Médicas e Biológicas, v.12, p.157-162, 2013. DOI: 10.9771/cmbio.v12i2.6955.

ZHANG, Y.; HENNING, S.M.; LEE, R.-P.; HUANG, J.; ZERLIN, A.; LI, Z.; HEBER, D. Turmeric and black pepper spices decrease lipid peroxidation in meat patties during cooking. International Journal of Food Sciences and Nutrition, v.66, p.260-265, 2015. DOI: 10.3109/09637486.2014.1000837.

$\overline{\text { Received on April 16, } 2016 \text { and accepted on April 26, } 2017}$

Pesq. agropec. bras., Brasília, v.52, n.11, p.1091-1098, nov. 2017

DOI: 10.1590/S0100-204X2017001100015 